\title{
A study of Daphnia-Leptodora-juvenile Percids interactions using a mathematical model in the biomanipulated Sulejow Reservoir
}

\author{
A. Wojtal ${ }^{1 *}$, D. Bogusz ${ }^{2}$, V. Menshutkin ${ }^{2}$, K. Izydorczyk ${ }^{2}$, P. Frankiewicz ${ }^{1}$, I. Wagner-Lotkowska ${ }^{1}$, M. Zalewski ${ }^{1,2}$ \\ ${ }^{1}$ Department of Applied Ecology, University of Lodz, 90-237 Lodz, Banacha 12/16 Str, Poland \\ 2 International Centre for Ecology Polish Academy of Science, Tylna 3 Str, 90-364 Lodz, Poland
}

\begin{abstract}
A model (DALIS 1.0) of pelagic zone trophic interactions was developed using long-term, comprehensive data sets of the Sulejow Reservoir. We calibrated the model using observations from the pelagic zone of the Sulejow Reservoir made between 1999 and 2001. The model performed well in the description of Daphnia sp. - L. kindtii interactions when hydrological conditions were stable. A discrepancy between observed and simulated results was found when water inflows were high, which washed out the biota. We suggested that the hydrological impacts should be coupled in the updated DALIS model. Using DALIS, we also tested two scenarios: the food web model (A) without Leptodora; and (B) without YOY fish, under both good and bad food conditions for Daphnia. Results indicated that Leptodora would have a more significant impact on the reduction of Daphnia biomass than juvenile fish during some periods. As the maintenance of high Daphnia densities is recognised as a key factor in top-down effects, the DALIS model may provide frameworks that support ongoing empirical work. It is therefore recommended that the model be incorporated into the programme of the Sulejow Reservoir restoration.
\end{abstract}

Keywords: Daphnia cucullata, Leptodora kindtii, juvenile Percids, trophic interactions, modelling.

\section{Introduction}

Eutrophication is actually the most important problem for freshwater ecosystem management (Harper 1992). In many lakes and reservoirs, the adverse symptom of eutrophication is the appearance of blue-green algae blooms, which may contain complex mixtures of microcystins and anatoxins (Carmichael, 1992) which are dangerous to human health (e.g. Falconer 1994). Lowland reservoirs are especially susceptible to eutrophication (Straskraba \& Tundisi 1999). Most of these ecosystems play a very important role as drinking water supplies and recreational waterbodies in Poland (Jurczak et al. 2004). One of them is the shallow Sulejow Reservoir located in the central Poland, which supplies drinking water to about 1 million people (Lodz Aglomeration), despite a high concentration of cyanobacteria hepatotoxins (see reservoir characteristics in the "study area" section) during the summer. The restoration programme of this reservoir has been applied as a result of the high vulnerability of Sulejow Reservoir to nutrient loading. This programme integrated classical methods of landscape ecology and recent advances in biogeochemistry at

\footnotetext{
* Corresponding author: E-mail: adwoj@biol.uni.lodz.pl
}

the catchment scale, e.g.: rehabilitating buffer zones, renaturalising river channel morphology, regulating the flow regime of the incoming river as a means of modifying the nutrient supply, creating wetland systems, and applying a variety of biomanipulation techniques (Zalewski 1999). The biomanipulation strategies of the Sulejow Reservoir were proposed on the basis of comprehensive, ten year long research concerning the structure of fish communities and interactions between juvenile Percids, predatory Cladocera (Leptodora kindtii, Focke), filtering Cladocera (mainly two species of Daphnia: D. cucullata, Sars and D. longispina, O.F.Müller), and phytoplankton (e.g. Zalewski et al. 1990, Frankiewicz et al. 1996, Tarczynska et al. 2001, Wojtal et al. 2004). As a result of these research, the important role of juvenile Percids (but not adult cyprinids) and L. kindtii in the midsummer decline of the dominant species of filtering zooplankton, Daphnia cucullata was revealed (Frankiewicz et al. 2002, Wojtal et al. 2004). Our present study focused on determining the precise dependence of Daphnia seasonal dynamics and fluctuations on the structure of the Reservoir's pelagic food web.

It is generally accepted that Daphnia are the most significant grazers of the filter-feeding zooplankton in lakes (e.g. Shapiro 1980, Sterner 1989). Therefore, influences 
of bottom-up and top-down interactions on Daphnia population dynamics are the centre of attention in plankton ecology research (e.g. De Stasio 1995, Boersma et al. 1996). The strength of these interactions depends first of all on the trophic state of the ecosystem (Jeppesen 1998). According to Carney and Elser (1990) the role of Daphnia sp. as an efficient controller of phytoplankton biomass is most significant in intermediately nutrient-rich ecosystems. It results from relatively low predatory pressure on its population. In hypertrophic lakes, the shift of fish community structure towards dominance of planktivorous species feeding on large-bodied zooplankton, diminishes the efficiency of Daphnia. In oligotrophic lakes, increased pressure on Daphnia is an effect of the lower availability of food and the lack of or weakly developed community of predatory fish (Jeppesen 1998). Moreover, predator pressure is higher in shallow lakes relative to deep lakes (Jeppesen et al. 2003). Consequently, the midsummer decline of Daphnia sp. in shallow, eutrophic lakes is often explained by a strong pressure of planktivorous fish. Recently, however, more recognition has been given to the fact that most adult planktivorous fish can be also benthivorous and, to a large extent, use benthic food sources (Vander Zander \& Vadeboncoeur 2002). Thus, Daphnia sp. dynamics are mostly controlled by young-of-the-year (YOY) fish, both planktivores (Hambright 1994) and intentionally promoted piscivores (Mills et al. 1987, Gliwicz \& Pijanowska 1989). Juvenile fish may be able to strongly control biomass of larger zooplankton species (Daphnia sp., adult copepods) by predation, especially in littoral zones (Zalewski et al. 1990). Significant impacts of YOY fish were also observed in mesocosm experiments, where the density of fish was generally high (Cryer et al. 1986, Hulsmann \& Mehner 1997). However, results of field studies often exhibit a relatively small effect by $0+$ juvenile fish on the decline of midsummer Daphnia (Wu \& Culver, 1992, Boersma et al. 1996, Mehner et al. 1998). These results indicate that not only YOY fish predation, but also other factors, can influence zooplankton dynamics in the pelagic zone of a lake. Other important biotic mechanisms (partly reviewed by Benndorf et al. 2000) are:

a) The seasonal shift of lakes/reservoir succession from the dominance of edible to inedible phytoplankton (Gliwicz 1977, Sommer et al. 1986, Boersma et al. 1996);

b) competition (De Mott 1989); and

c) high abundance of large invertebrate predators (e.g.: Leptodora kindtii, Bythotrephes sp. or Chaoborus sp.) which can significantly reduce the population of herbivorous Cladocera during periods of low planktivorous fish density (Gliwicz \& Prejs 1977, Lunte \& Luecke 1990, Branstrator \& Lehman 1991, Herzig 1995, Matveev 1995).

Leptodora kindtii occurs in the pelagic zone of many temperate, eutrophic lakes. As it is intolerant to low temperatures, it achieves high abundance during summer months (Garton et al. 1990), reaching up to $16-18 \mathrm{~mm}$ in body length. The predation rate of $L$. kindtii is influenced by temperature, prey density and both predator and prey size, and can reach 12 prey items per predator per day (Herzig \& Auer 1990). Consequently, during summer density increases, L. kindtii is able to reduce between 10 and 51\% of Daphnia biomass (Herzig 1994, Wojtal et al. 2004). Thus, Leptodora can effectively control cladoceran populations in lakes (Lunte \& Luecke 1990, Wojtal et al. 1999).

On the other hand, seasonal fluctuations of many planktonic species are strongly influenced by abiotic factors, and temperature is among the most important of these factors. This is not only a matter of the direct effect of temperature on both food availability and quality in spring (Moore et al. 1996). Early summer temperature also influences the growth rate of YOY fish and, thus, their predation potential (Mehner et al. 1996). Water temperature during winter and early spring may also have a strong impact on Daphnia sp. mortality in summer. Low temperature during this period results in high early spring (April and May) biomass of Daphnia and consequently, long lasting (>30 days) midsummer decline (Benndorf et al. 2001).

All of the above-described factors strongly influence Daphnia spp. biomass dynamics and are very important for establishing proper biomanipulation strategies. In order to estimate such complex biotic interactions, a modelling approach was used. Nowadays, applying the modern limnological research dynamic mathematical models enables us to explain the structural changes observed in water ecosystems. These types of models may be especially important in lake management as they allow qualitative predictions of the success or failure of biomanipulation (Jorgensen \& De Bernardi 1998). Therefore, the basic aim of our study in biomanipulation aspects was detailed recognition and quantification of interactions between phytoplankton-Daphnia cucullata-L. kindtii-juvenilePercids in the pelagic zone of the Sulejow Reservoir using a mathematical model. This aim was realized by: (1) construction of the DALIS model (Daphnia-Leptodora Interactions Simulations) on the basis of available data collected during our empirical research (both field and experimental data) on the Sulejow Reservoir; (2) estimation, if the model predictions are concordant with the values given by the empirical 
study (calibration of the DALIS model); and (3) quantitative comparison of the contribution of $L$. kindtii and juvenile Percids to the decline of Daphnia cucullata biomass in different food conditions using model simulations.

\section{Study area}

The Sulejow Reservoir is a 35 year old lowland reservoir situated $\left(51^{\circ} 22^{\prime}-51^{\circ} 28^{\prime} \mathrm{N} \& 1^{\circ} 51^{\prime}-20^{\circ} 01^{\prime} \mathrm{E}\right.$; Fig. 1) on $138,9 \mathrm{~km}$ of the Pilica River (the Vistula River catchment). The major tributaries of the reservoir, conveying more than $96 \%$ of its water are the Pilica River (mean discharge $24.2 \mathrm{~m}^{3} \mathrm{~s}^{-1}$ ) and the Luciaza River (mean discharge $3.0 \mathrm{~m}^{3} \mathrm{~s}^{-1}$ ).

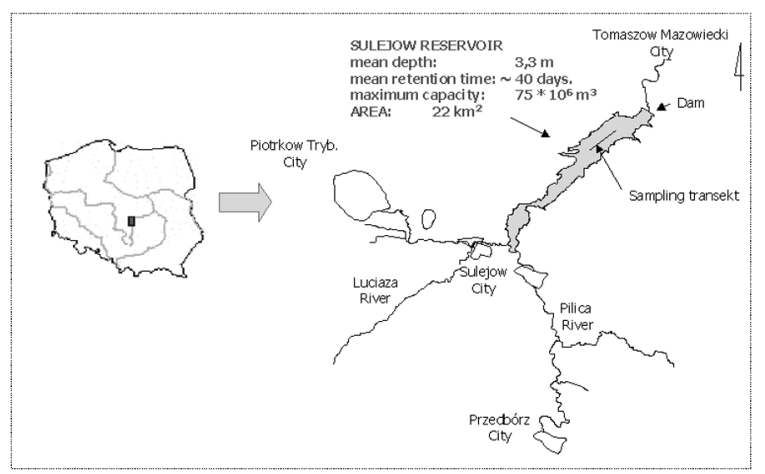

Fig. 1. The general location and a detailed map of Sulejow Reservoir.

The maximum length of the reservoir is $15.5 \mathrm{~km}$ and the maximum width is $2.1 \mathrm{~km}$. At maximum capacity ( 75 $\mathrm{x} 10^{6} \mathrm{~m}^{3}$ ), the reservoir covers $22 \mathrm{~km}^{2}$, with a mean depth of $3.3 \mathrm{~m}$ and a maximum depth of $11 \mathrm{~m}$. The mean monthly water retention time during the years 1999-2001 was 42 days, and varied from 101.9 to 7 days. Due to high water level fluctuations, the reservoir's littoral zone is almost devoid of macrophytes. The reservoir's direct catchment is covered mainly by agricultural land $(50 \%$ arable land, $13 \%$ meadows and pastures, $1 \%$ orchards) and forests (31\%). The shoreline length is about $54 \mathrm{~km}$.

The Sulejow Reservoir is a eutrophic ecosystem: the mean total phosphorus concentration at the spring overturn was $0.366 \mathrm{mg} \mathrm{dm}^{-3}$ and soluble inorganic nitrogen concentration varied from 0.1 to $0.5 \mathrm{mg} \mathrm{dm}^{-3}$ nitrate. The mean chlorophyll concentration during growth seasons (1994-2001) was about $30 \mathrm{mg} \mathrm{m}^{-3}$, but exceeded $120 \mathrm{mg}$ $\mathrm{m}^{-3}$ during phytoplankton blooms. Concentrations of cyanobacteria hepatotoxin (microcystin-LR (MC-LR),
microcystin-RR (MC-RR) and microcystin-YR (MC-YR)) during the growing season varied from 12 to $860 \mu \mathrm{g} \mathrm{g}^{-1}$ dry weight of phytoplankton biomass (data from 1993-96; Tarczynska et al. 2001). In recent years, the mean concentration of hepatotoxin during the growth

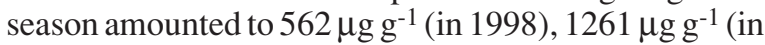
2000) and $1018 \mu \mathrm{g} \mathrm{g}^{-1}$ (in 2001) dry weight of phytoplankton biomass (Jurczak et al. 2004). The highest concentrations were observed in September and October (Zalewski et al. 2000).

In the initial stage of seasonal succession, phytoplankton consists mostly of diatoms (Cyclotella comensis Grun., C. radiosa Grun., Cyclostephanos dubius (Hust.) Round., Asterionella formosa Hassall, Tabellaria flocculosa (Roth.) Knud., Fragilaria crotonensis Lyngb.), cryptophytes (Cryptomonas ovata var. palustris Ehr.) and green algae (Chlamydomonas sp. Ehr., Scenedesmus quadricauda (Turp.) Bréb., S. acuminatus (Lagerh.) Chod.). In the summer, blooms of cyanobacteria (mainly Microcystis aeruginosa Kütz. and Aphanizomenon flos-aquae (L.) Ralfs) have frequently been observed.

Gill net catches regularly conducted since 1993 have shown a very stable fish stock composition during the nineties, with $47 \%$ consisting (in terms of biomass) of common bream, Abramis brama L., 20\% of pikeperch, Stizostedion lucioperca L., and 10\% of white bream, Abramis bjöerkna L. and roach, Rutilus rutilus L.. Other fish species regularly observed in gillnet catches were perch, Perca fluviatilis L., bleak, Alburnus alburnus L., ruffe, Gymnocephalus cernuus L., asp, Aspius aspius L. and pike, Esox lucius L. (Frankiewicz et al. 1999).

\section{Sampling procedure}

Samples of phytoplankton, zooplankton and young-of-the-year (YOY) fish were taken in the pelagic zone of the reservoir at the same sampling station, located 3-4 km upstream from the dam. The sampling procedures have been the same since 1994. Sampling was carried out weekly.

YOY Percids (Perca fluviatilis and Stizostedion lucioperca), the most numerous juvenile fish present in pelagic zone of the reservoir, were sampled at night with a bongo net (a single net, $0.5 \mathrm{~m}$ diameter; $1.0 \mathrm{~mm}$ mesh size), pushed by a motor boat for 2 minutes with a speed of $2 \mathrm{~ms}^{-1}$, at three depths: 1,2 and 4 meters with three replicates for each depth. Weight and total length of the collected fish were measured. All the collected individuals were anaesthetised and preserved in $10 \%$ formaline for laboratory analysis. The stomach contents were identified and counted under a Nikon 102 microscope. For cal- 
culation of daily consumption of YOY fish, an equation of Elliot and Persson (1978) was used. The results concerning diet composition and daily consumption of juvenile Percids for the 1994-95 period (used for model construction) were presented in Wojtal et al. (2004).

Zooplankton was sampled using a 5-litre Bernatowicz sampler, at four depths: 1, 2, 3 and 4 meters (with 4-5 replicates for each depth) and filtered with a $50 \mu \mathrm{m}$ mesh size plankton net. This procedure was found to be accurate for estimating Leptodora kindtii density (Wojtal et al. 1999). As diurnal vertical migration of zooplankton has not been observed in this shallow reservoir, and zooplankton were evenly distributed throughout the whole water column, samples from all the three/four depths were integrated. Sampling was carried out from the end of May until September. Collected zooplankton were preserved in 4\% Lugol's solution. The samples were identified and counted under a Nikon 115 microscope. Zooplankton were measured to calculate the index of prey preferences. Biomass for a particular zooplankton genus (wet weight, ww) was estimated on the basis of species-specific length/weight regressions (biomass of L . kindtii - Karabin 1974, biomass of other zooplankton taxa-Bottrell et al. 1976, Horn 1991). In the case of Leptodora kindtii, prey present in their basket were identified and measured. The estimations of birth and death rates of Daphnia sp. and the predation rate of L. kindtii [prey Leptodora ${ }^{-1}$ day $^{-1}$ ] were published by Wojtal et al. (2004).

Phytoplankton species composition and biomass were measured in a 1-litre integrated water sample taken at the same location as the zooplankton. The samples were preserved in Lugol's solution and were subjected to sedimentation in the laboratory. Algae were counted using a Fusch-Rosenthal counting cell. The phytoplankton biomass was determined based on a volumetric analysis of cells using geometric approximation (Reynolds 1984).

\section{Description of the Model}

The model was run for 122 days, corresponding to period between the $1^{\text {st }}$ of June and the $30^{\text {th }}$ of September. STELLA 8.0 was used as the programming language (Hannon \& Ruth 2001). The simplified conceptual diagram (a) and an overview (b) of the model is presented in Fig. 2. Overview created by Stella programme includes: target variables (called stocks and representing three key functional organisms biomass dynamics), directions of trophic interactions (energy inflows or outflows), distribution of coeficients (there are converters indicating food choices, consumption rates and metabolic efficiency ratios) and connectors linking model elements.
Model parameters with abbreviations using in Fig. 2 are presented in Table I. The values of the model parameters are not included in the Table I as most of them are time-variable values. Changeability of the basic coefficients is demonstrated on the Fig. 3. Mathematical relationships between DALIS parameters are presented below, in sub-chapters.

There are three target variables considered in the model:

a) Daphnia cucullata (the dominant species of herbivorous Cladocera in the Sulejow Reservoir), represented in the model as $\mathrm{D}$;

b) Leptodora kindtii, the dominant invertebrate predator of the pelagic zone $(\mathrm{L})$;

c) YOY Percids - pikeperch and perch (F).

Results of phytoplankton, represented in the model as $\mathrm{P}$ ("edible") and A ("inedible"), in addition to data of water temperature (TEMP), were also used as a forcing functions.

The effect of temperature, as one of the most important abiotic factor strongly determining dynamic and demography of organisms, was calculated according to equation (Jorgensen et al. 1981):

$$
R T E M P=\exp ^{\wedge}\left(-2.5\left|\frac{\text { TEMPERATURE }-20.5}{25}\right|\right)
$$

\section{Population dynamics and consumption of Daphnia sp.}

The dynamics of herbivores zooplankton (Daphnia sp.) depends on the filtration rate of phytoplankton (DPF), the filtration rate of cyanobacteria (DAF), the influence of a toxical algae bloom on Daphnia sp. (AB), the respiration rate of Daphnia sp. (DR), the natural and density-dependent mortality rate of Daphnia sp. (DM), the mortality due to predation of fish (DFP) and the mortality due to predation of Leptodora kindtii (DLP). Thus the dynamics of Daphnia is modelled with the following ordinary differential equation:

$\mathrm{D}(t)=$

$\mathrm{D}(t-\mathrm{d} t)+(\mathrm{DPF}+\mathrm{DAF}-\mathrm{AB}-\mathrm{DR}-\mathrm{DM}-\mathrm{DFP}-\mathrm{DLP}) \mathrm{d} t$.

The consumption of Daphnia sp. (inflow parameters) is composed of two parts: DPF (concerning phytoplankton belonging to the "edible" size range of 2.0-31.0 mm; Reynolds 1984) and DAF (concerning net phytoplankton belonging to the "inedible" size range of $>31.0 \mathrm{~mm}-$ mainly cyanobacteria; Reynolds 1984). Daphnia filtration rate of phytoplankton (DPF) was given as minimum 
A

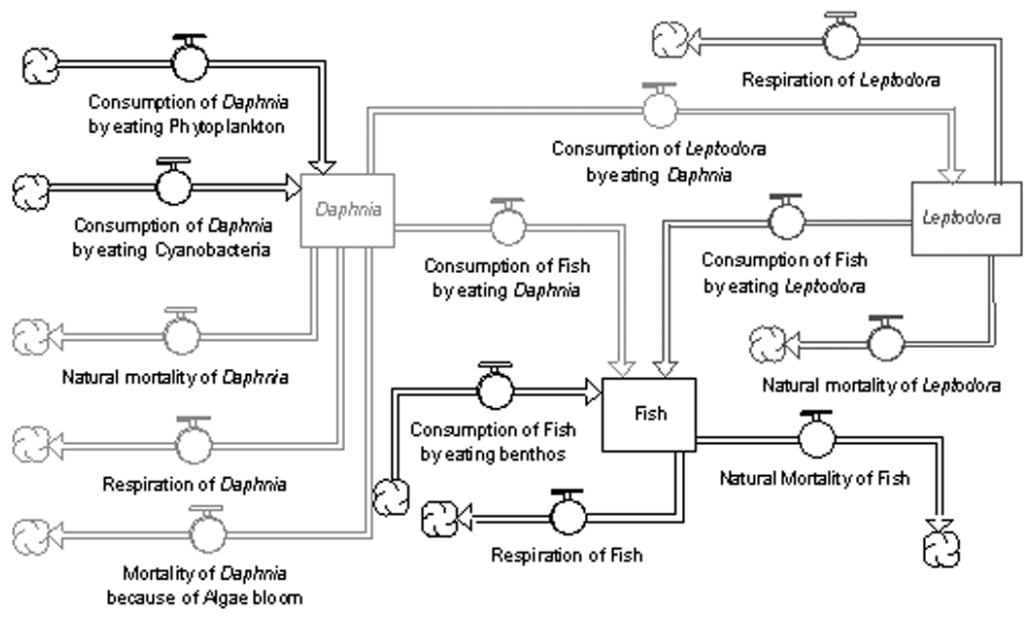

$\mathrm{B}$

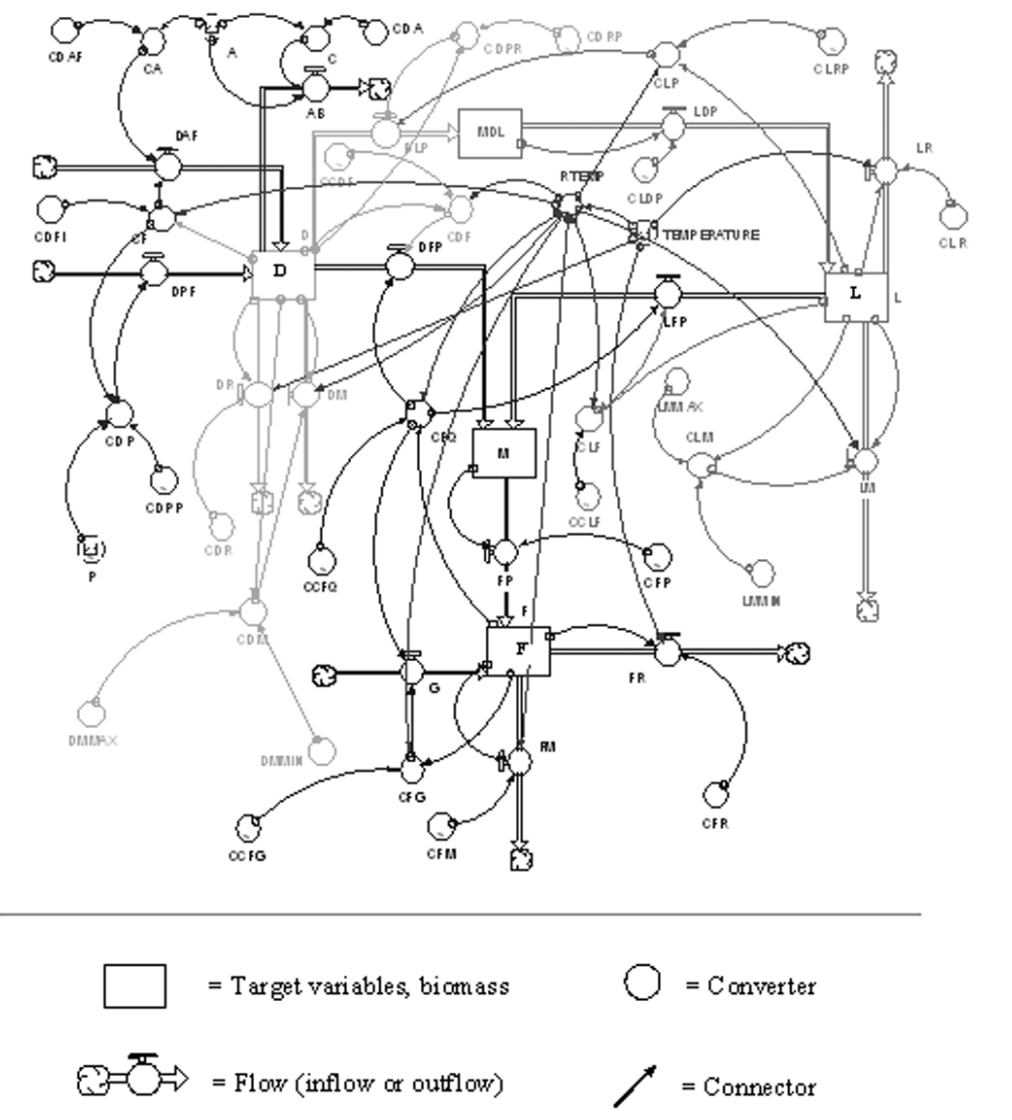

Fig. 2. Conceptual diagram (a) and an overview (b) of the DALIS 1.0 model by Stella program. Abbreviations are given in Table 1. Description of the symbols (according to Stella Technical Documentation): Target variables - (called also stocks) are accumulations. They collect whatever flows into them, net of whatever flows out of them. Flow - fills and drains accumulations. The unfilled arrow head on the flow pipe indicates the direction of positive flow. Converter - The converter serves a utilitarian role in the software. It holds values for constants, defines external inputs to the model, calculates algebraic relationships, and serves as the repository for graphical functions. In general, it converts inputs into outputs. Connectors - connect model elements (figure presents the action connectors). 
Table I. Parameters of the DALIS (1.0) model. Symbols marked by stars are literature-based constant values (references in the text).

\begin{tabular}{|c|c|c|}
\hline SYMBOL & DESCRIPTION & UNIT \\
\hline \multicolumn{3}{|l|}{ Daphnia sp. } \\
\hline $\mathrm{D}$ & Biomass of Daphnia & $\mathrm{mg} \mathrm{ww}^{-1}$ \\
\hline DPF & Daphnia filtration on phytoplankton & $\mathrm{mg} \mathrm{ind}^{-1}(24 \mathrm{~h})^{-1}$ \\
\hline CDP & Daphnia predation rate on phytoplankton (coefficient of maintenance rate) & - \\
\hline CDPP* & Coefficient for CDP & - \\
\hline DAF & Daphnia filtration on cyanobacteria & $m g$ ind $^{-1}(24 \mathrm{~h})^{-1}$ \\
\hline CA & Daphnia predation rate on cyanobacteria (coefficient of maintenance rate) & - \\
\hline CDAF & Coefficient for CA & - \\
\hline DR & Respiration of Daphnia & $\mathrm{mg} \mathrm{O}_{2}$ ind $^{-1}(24 \mathrm{~h})^{-1}$ \\
\hline $\mathrm{CDR}^{*}$ & Coefficient of respiration rate for Daphnia & - \\
\hline DM & Mortality of Daphnia (natural) & $(24 h)^{-1}$ \\
\hline CDM & Coefficient of mortality rate for Daphnia & - \\
\hline $\mathrm{AB}$ & Mortality of Daphnia because of algae bloom & $(24 h)^{-1}$ \\
\hline $\mathrm{C}$ & Coefficient for $\mathrm{AB}$ & - \\
\hline CDA & Coefficient for $\mathrm{C}$ & - \\
\hline DMMAX & Coefficient of maximal rate of Daphnia mortality & - \\
\hline DMMIN & Coefficient of minimal rate of Daphnia mortality & - \\
\hline $\mathrm{CF}$ & Coefficient of maximal ratio for Daphnia & - \\
\hline CDFI & Coefficient for CF & - \\
\hline CLDP* & Caloric value of Daphnia & $\mathrm{Jg}^{-1}$ \\
\hline \multicolumn{3}{|l|}{ Leptodora kindtii } \\
\hline$\overline{\mathrm{L}}$ & Biomass of Leptodora & $\mathrm{mg} \mathrm{ww} \mathrm{l}^{-1}$ \\
\hline LDP & Assimilation for Leptodora & $\operatorname{mg}(24 h)^{-1}$ \\
\hline LR & Respiration of Leptodora & $\mathrm{mg} \mathrm{O}_{2}$ ind $^{-1}(24 \mathrm{~h})^{-1}$ \\
\hline CLR* & Coefficient of respiration rate for Leptodora & - \\
\hline LM & Mortality of Leptodora & $(24 h)^{-1}$ \\
\hline CLM & Coefficient of mortality rate for Leptodora & - \\
\hline LMMAX & Coefficient of maximal rate of Leptodora mortality & - \\
\hline LMMIN & Coefficient of minimal rate of Leptodora mortality & - \\
\hline MDL & Coefficient of Leptodora production & - \\
\hline DLP & Leptodora predation on Daphnia & $\mathrm{mg}(24 \mathrm{~h})^{-1}$ \\
\hline CLP & Leptodora predation rate on Daphnia (coefficient of maintenance rate) & - \\
\hline CLRP & Coefficient for CLP & - \\
\hline CDPR & Coefficient of consumption by Leptodora & - \\
\hline CDRP & Coefficient for CDPR & - \\
\hline \multicolumn{3}{|l|}{ YOY fish } \\
\hline $\mathrm{F}$ & Biomass of fish & $\mathrm{g} \mathrm{m}^{-3}$ \\
\hline FP & Assimilation for fish & $m g(24 h)^{-1}$ \\
\hline CFP & Coefficient for FP & - \\
\hline FR & Respiration of fish & $\mathrm{mg} \mathrm{O}_{2}$ ind $^{-1}(24 \mathrm{~h})^{-1}$ \\
\hline CFR* & Coefficient of respiration rate for fish & - \\
\hline FM & Mortality of fish & $(24 h)^{-1}$ \\
\hline CFM & Coefficient of mortality rate for fish & - \\
\hline M & Coefficient of fish production & - \\
\hline DFP & Fish predation on Daphnia & $m g(24 h)^{-1}$ \\
\hline $\mathrm{CDF}$ & Coefficient of Daphnia consumption by fish & - \\
\hline $\mathrm{CCDF}$ & Coefficient for CDF & - \\
\hline LFP & Fish predation on Leptodora & $\operatorname{mg}(24 \mathrm{~h})^{-1}$ \\
\hline CLF & Coefficient of fish predation rate on Leptodora & - \\
\hline CCLF & Coefficient for CLF & - \\
\hline G & Contribution of bentic prey to fish food & $\mathrm{mg}$ \\
\hline CFG & Coefficient of maximal ratio for fish & - \\
\hline CCFG & Coefficient for CFG & - \\
\hline CFQ & Coefficient of maintenance rate for fish & - \\
\hline CCFQ & Coefficient for CFQ & - \\
\hline \multicolumn{3}{|l|}{ Phytoplankton } \\
\hline $\mathrm{P}$ Cyanobacteria & Biomass of phytoplankton & $\mathrm{mg}$ ww $\mathrm{l}^{-1}$ \\
\hline $\mathrm{A}$ & Biomass of cyanobacteria & $\mathrm{mg} \mathrm{ww} \mathrm{l}^{-1}$ \\
\hline \multicolumn{3}{|l|}{ Temperature } \\
\hline $\mathrm{T}$ & Temperature & ${ }^{\circ} \mathrm{C}$ \\
\hline RTEMP & Coefficient of temperature & - \\
\hline
\end{tabular}


$\mathbf{A}$


G

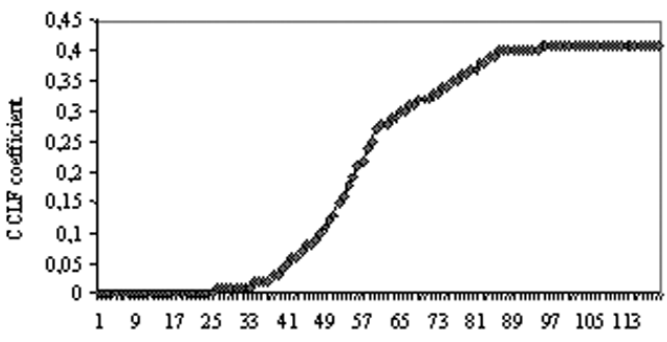

C
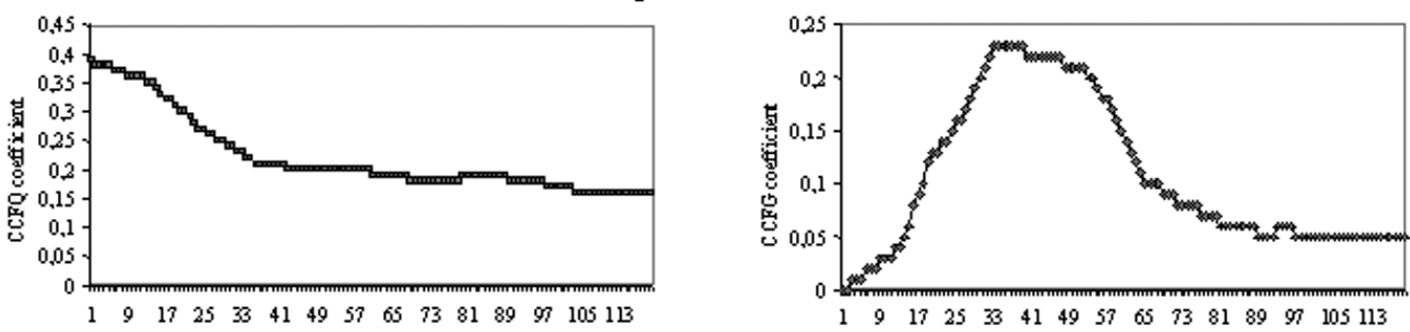

D
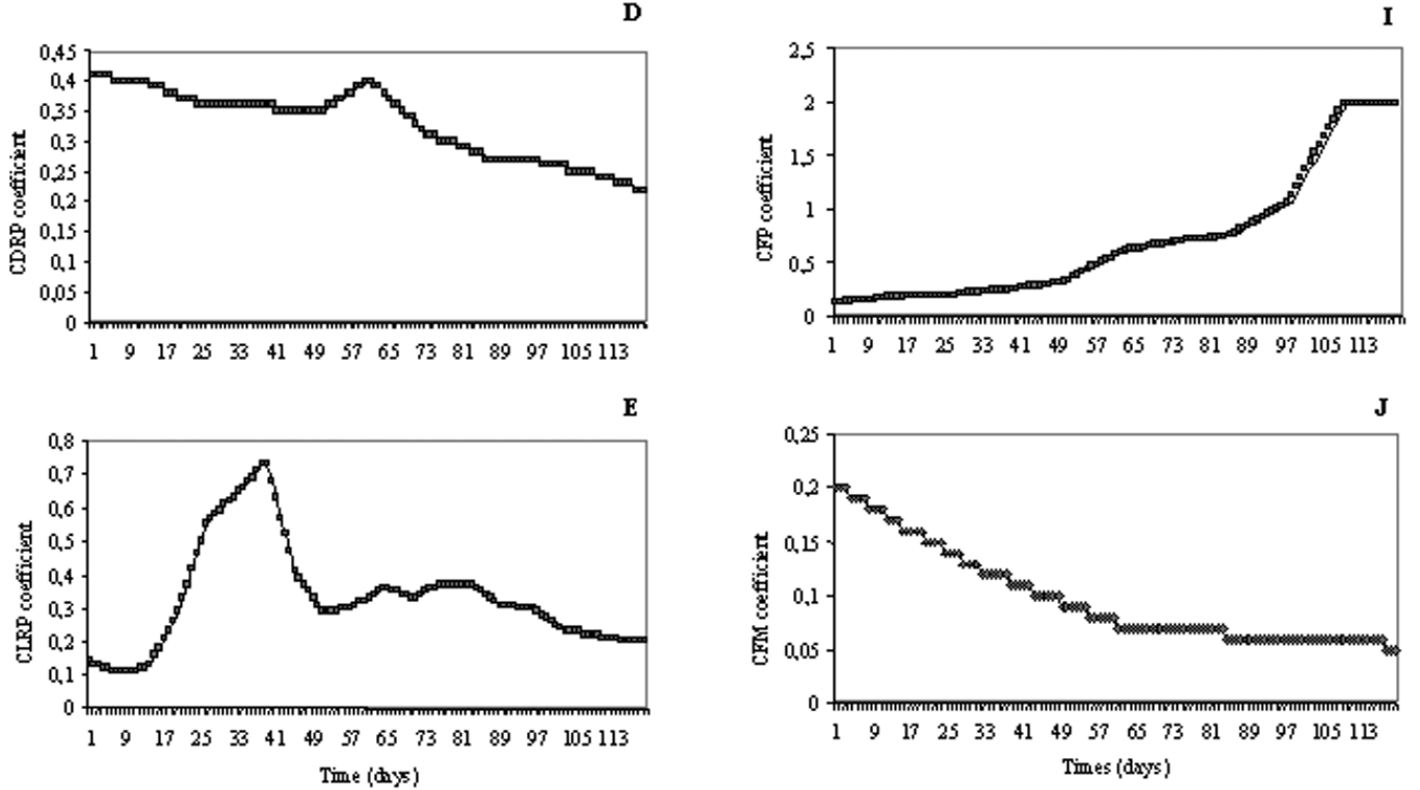

Fig. 3. Changeability of the time variable values of the DALIS model coefficients. Abbreviations as in Table I. 
value of the requirement $(\mathrm{CF})$ and availability $\left(\mathrm{P}^{*} \mathrm{CDPP}\right)$ of "edible" food calculated from:

$\mathrm{DPF}=$ DELAY (MIN (P* CDPP, CF $), 0.75)$.

The coefficient of Daphnia consumption (CDPP) was calculated based on the graph of caloric value (Fig. 3a) for phytoplankton (Sorokin 1999). The rate of food digestion was calculated according to Winberg (1968) and Ivanowa (1985) and the value $0.75 \mathrm{day}^{-1}$ was used in equation (3). The DELAY function returns a delayed value of $\left(\mathrm{P}^{*} \mathrm{CDPP}, \mathrm{CF}\right)$ using a fixed lag time $(0.75$ day $\left.^{-1}\right)$. The coefficient of the maximal ratio for Daphnia (CF) was given by:

$\mathrm{CF}=\mathrm{D} * \mathrm{CDFI} * \mathrm{RTEMP}$,

where CDFI (coefficient for CF) $=0.9\left(\mathrm{~m}^{-3} \mathrm{Cday}^{-1}\right)$ (Kmet \& Straskraba 2004) and RTEMP means coefficient of temperature (see Eq. 1).

Filtration rate of cyanobacteria (DAF) was given by analogy as the minimum value of the requirement $(\mathrm{CF})$ and availability (A*CDAF) of "inedible" food calculated from:

DAF $=$ DELAY $($ MIN $(A *$ CDAF, CF $), 0.75)$,

where CDAF (caloric value of cyanobacteria) $=0.27$ (Sorokin 1999)

Decrease of Daphnia population biomass was an effect of the outflow parameters. The one of an outflow parameter was the mortality of Daphnia due to algal blooms (AB). Cyanobacteria cells $(<31 \mathrm{~mm}$ diameter $)$ were accepted as an edible food for Daphnia in concentrations below $3 \mathrm{mg} \mathrm{dm}^{-3}$ according to Nebaeus (1984). Higher cyanobacteria biomass constituted a bloom and was determined to be unavailable as food for herbivorous zooplankton, as is given by the equation:

$\mathrm{AB}=\mathrm{IF} A>3$ THEN $(\mathrm{CDA} * \mathrm{~A})$ ELSE 0,

where $\mathrm{A}$ is the biomass of cyanobacteria and CDA (the coefficient of Daphnia mortality due to algal bloom) = 0.036 day $^{-1}$ (Kmet \& Straskraba 2004).

Respiration of Daphnia (DR) was calculated as the product of the Daphnia population dynamics, the coefficient of Daphnia respiration rate CDR $=0.15$ (Sushchenya 1972), and the optimal temperature for respiration $=20^{\circ} \mathrm{C}$ :

$\mathrm{DR}=\mathrm{D} * \mathrm{CDR} * 2.3^{\wedge}(($ TEMPERATURE -20$) / 10),(7)$

Reference temperatures for Daphnia $\left(20^{\circ} \mathrm{C}\right.$ or $\left.293 \mathrm{~K}\right)$ represents the temperature at which physiological rates had been measured, i.e. if ambient temperature T equals reference temperature $\left(20^{\circ} \mathrm{C}\right)$ the temperature correction factor $f(\mathrm{~T})$ becomes one (Rinke \& Vijverberg 2005). Temperature formula were used according to Jorgensen et al. (1981).
The mortality of Daphnia (DM) was calculated using the equation:

$\mathrm{DM}=\mathrm{D} * \mathrm{CDM} * \mathrm{RTEMP}$,

where CDM (the coefficient of Daphnia mortality rate) $=0.01$ (according to Wojtal 2000, and Rinke \& Vijverberg 2005).

The fish predation of Daphnia (DFP) was given as the minimum value of the coefficient of Daphnia consumption by fish $(\mathrm{CDF})$ and the coefficient of maintenance rate for fish (CFQ):

$\mathrm{DFP}=\mathrm{MIN}(\mathrm{CDF}, \mathrm{CFQ})$,

where $\mathrm{CDF}$ is given by the equation:

$\mathrm{CDF}=\mathrm{D} * \mathrm{CCDF} * \mathrm{RTEMP}$.

Changeability of the CCDF is demonstrated in Fig. $3 \mathrm{~b}$.

CFQ was calculated from:

$\mathrm{CFQ}=\mathrm{F} * \mathrm{CCFQ} * \mathrm{RTEMP}$.

Relative food requirement (CCFQ) decreases during the growth of YOY fish (Fig. 3c) due to the lower maintenance cost per unit body mass (Wootton 1990).

Leptodora kindtii predation on Daphnia (DLP) was calculated as the minimum value of the requirement (CLP) and availability (D*CDRP) of food (Daphnia as prey) according to the equation:

$\mathrm{DLP}=\mathrm{MIN}(\mathrm{D} * \mathrm{CDRP}, \mathrm{CLP})$.

The coefficient of consumption of $L$. kindtii by eating Daphnia sp. (CDRP) was calculated as the minimum requirement of food and available food. This is based on the key assumption of the Liebig Low. Time variability of the CDRP coefficient is demonstrated in Fig. $3 \mathrm{~d}$.

CLP is the Leptodora predation rate on Daphnia (coefficient of maintenance rate) given by:

$\mathrm{CLP}=\mathrm{L} * \mathrm{CLRP} * \mathrm{RTEMP}$.

The predatory rate (CLRP) was estimated for the temperature and density of Leptodora prey (Daphnia sp.) on the given sampling date. Calculations were described in detail by Wojtal et al. 2004 (changeability of the CLRP is showed on the Fig. 3e).

\section{Population dynamics and consumption of Leptodora kindtii.}

The dynamic of Leptodora kindtii is regulated by it's assimilation rate (LDP), respiration rate (LR), natural and density-dependent mortality rate of $L$. kindtii (LM), and mortality rate of Leptodora due to predation of fish (LFP). This dynamic is modelled using the following ordinary differential equation:

$\mathrm{L}(t)=\mathrm{L}(t-\mathrm{d} t)+(\mathrm{LDP}-\mathrm{LR}-\mathrm{LM}-\mathrm{LFP}) \mathrm{d} t$. 
Assimilation rate of Leptodora (LDP) was calculated from:

$$
\text { LDP = DELAY (MDL * CLDP, 0.75). }
$$

Caloric value of Leptodora food (CLDP) was estimated on the basis of the index of the calorific value of zooplankton (Prus 1970). Time variability of the CLDP coefficient is demonstrated in Fig. 3f. MDL is the coefficient of Leptodora production modelled using the equation:

$\operatorname{MDL}(t)=\operatorname{MDL}(t-\mathrm{d} t)+(\mathrm{DLP}-\mathrm{LDP}) \mathrm{d} t$.

The respiration rate of Leptodora was calculated by analogy to Daphnia DR (Eq. 7):

$$
\mathrm{LR}=\mathrm{L} * \mathrm{CLR} * 2.3^{\wedge}((\text { TEMPERATURE }-20) / 10) \text {, }
$$

where CLR (the coefficient of respiration rate for Leptodora $)=0.14$ (Hillbricht-Ilkowska \& Karabin 1970).

The natural and density-dependent mortality rate of $L$. kindtii (LM) was worked out through an analogy to Daphnia $\mathrm{DM}$ (Eq. 8):

$$
\mathrm{LM}=\mathrm{L} * \mathrm{CLM} * \mathrm{RTEMP} \text {, }
$$

where CLM (the coefficient of mortality rate for Leptodora $)=0.01$ (Menshutkin, unpublished).

The fish predation of Leptodora (LFP) was given (similar to Eq. 9) as the minimum value of the the coefficient of Leptodoraa consumption by fish (CLF) and the coefficient of maintenance rate for fish (CFQ):

$\mathrm{LFP}=\mathrm{MIN}(\mathrm{CLF}, \mathrm{CFQ})$,

where CLF is coefficient of fish predation rate on Leptodora modelled with following equation:

$\mathrm{CLF}=\mathrm{L} * \mathrm{CCLF} * \mathrm{RTEMP}$.

Changeability of the CCLF is demonstrated in Fig. $3 \mathrm{~g}$.

\section{Population dynamics and consumption of YOY} fish.

The dynamics of fish are modified by consumption of benthos (G), consumption of Leptodora and Daphnia (LFP and DEP), a fish respiration rate (FR), and a natural and density-dependent mortality rate of fish (FM) according to the following ordinary differential equation:

$\mathrm{F}(t)=\mathrm{F}(t-\mathrm{d} t)+(\mathrm{G}+\mathrm{FP}-\mathrm{FM}-\mathrm{FR}) \mathrm{d} t$.

The consumption of fish is composed of three parameters: the coefficient of Daphnia sp. consumption (CCDF), the coefficient of $L$. kindtii consumption (CCLF) and the coefficient of other food consumption (CCFG). The highest CCDF values were observed during June and the highest CCLF values were calculated in July. Shifts in the proportion of CCDF and CCLF during the season (Fig. 3b,g) were estimated using a chi ${ }^{2}$-test $\left(\mathrm{chi}^{2}=65.363, \mathrm{p}=0.0000\right.$ in $1994 ; \mathrm{chi}^{2}=22.441$, $\mathrm{p}=0.0004$; in 1995 and $\mathrm{chi}^{2}=40.181, \mathrm{p}=0.000$ in 1996; details in Wojtal 2000). Decreases in the contribution of zooplankton to the food of YOY fish during the summer, resulted from a lower availability of large zooplankters and improved profitability of larger benthic prey due to increased juvenile gap size (in accordance to the optimal foraging theory, Krebs \& Stephans 1986).

The contribution of benthic prey to fish food $(\mathrm{G})$ was given as a minimum value of the coefficient of maximal ratio for fish (CFG) and the coefficient of maintenance rate for fish (CFQ):

$\mathrm{G}=$ DELAY (MIN (CFG, CFQ),1),

where:

$\mathrm{CFG}=\mathrm{F} * \mathrm{CCFG} * \mathrm{RTEMP}$.

Changeability of the CCFG is demonstrated in Fig. $3 \mathrm{~h}$.

Assimilation rates of fish (FP) were calculated from:

$\mathrm{FP}=\operatorname{DELAY}(\mathrm{M} * \mathrm{CFP}, 1)$,

where $\mathrm{M}$ is the coefficient of fish production modelled by the equation:

$\mathrm{M}(t)=\mathrm{M}(t-\mathrm{d} t)+(\mathrm{DFP}+\mathrm{LFP}-\mathrm{FP}) \mathrm{d} t)$.

CFP, used in equation (24), is the coefficient of fish assimilation. The caloric value of fish prey CFP increases in the summer (Fig. 3i), while YOY fish shift from the suboptimal zooplankton to large benthic prey (more details in Wojtal 2000).

Mortality of fish was given by:

$\mathrm{FM}=\mathrm{F} * \mathrm{CFM} * \mathrm{RTEMP}$.

The mortality rate of YOY fish (CFM) in the pelagic zone of the Sulejow Reservoir was estimated based on Frankiewiczetal. (1999) data (Fig. 3j). It is in accordance with a general model of juvenile fish survivorship (Wootton 1990).

The respiration rate of fish was calculated by analogy to equations 7 and 17:

$\mathrm{FR}=\mathrm{F} * \mathrm{CFR} * 2.3^{\wedge}((\mathrm{TEMPERATURE}-20) / 10),(27)$

where CFR (the coefficient of respiration rate for fish) $=0.05$ (Wootton 1990).

\section{Results}

\section{Model calibration - comparison with the observations.}

In order to evaluate the effects of temperature, juvenile Percids and dynamics of phytoplankton communities biomass on Daphnia-Leptodora interactions, the model was tested using data from the pelagic zone of the Res- 
ervoir collected between 1999 and 2001 when significant differences in hydrological conditions between compared years existed. Simulations of the DALIS 1.0 for these years were compared with the observed biomass dynamics of zooplankton, and were analysed with the background of seasonal changes of abiotic conditions (temperature). Density of pelagic YOY Percids in 1999-2001 ranged from 0.1 to $0.5 \mathrm{ind} \mathrm{m}^{-3}$. Real values of phytoplankton dynamics observed in the reservoir from 1999-2001 (Fig. 4) were used in the model simulations.
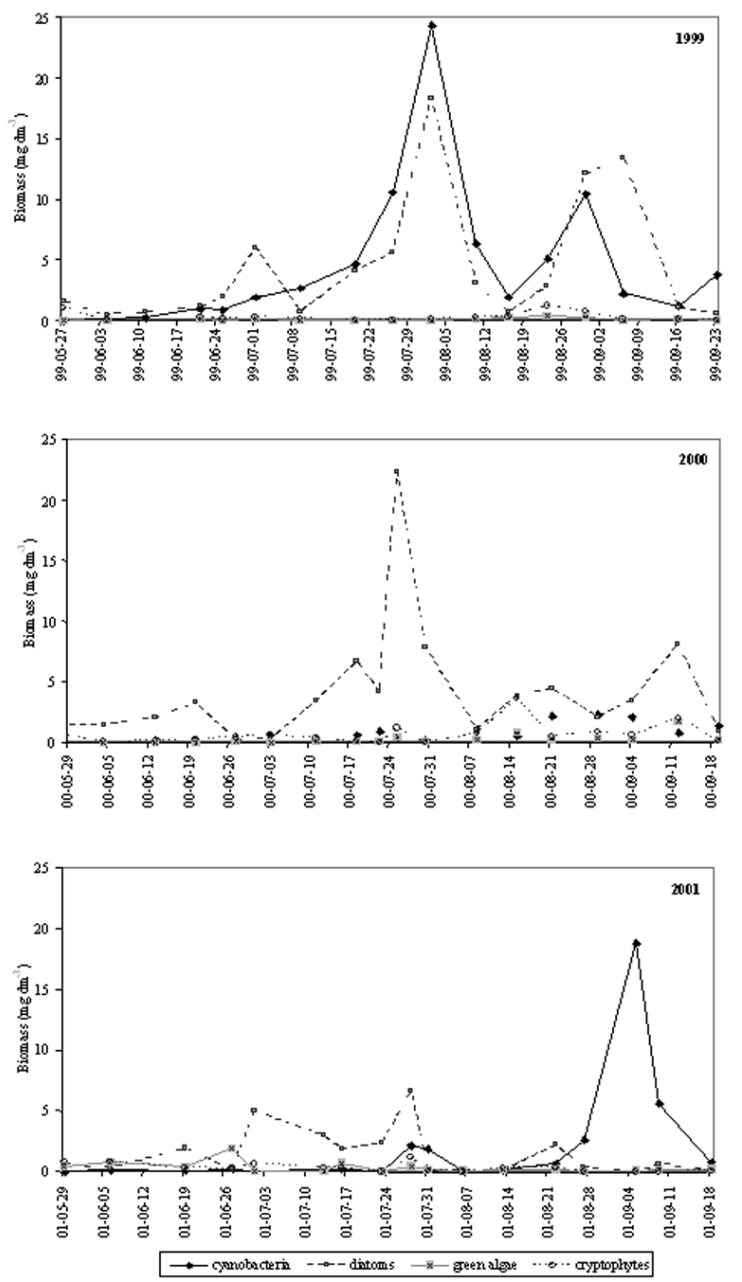

Fig. 4. Temporal dynamics of phytoplankton in the pelagic zone of the Sulejow Reservoir in 1999-2001.

\section{Year 1999}

During most of the sampling period in 1999, hydrological parameters of the two major tributaries were stable. The mean discharge of the Pilica and Luciaza rivers were $29.04 \mathrm{~m}^{3} \mathrm{~s}^{-1}$ and $3.3 \mathrm{~m}^{3} \mathrm{~s}^{-1}$, respectively. In the second part of June, however, an intensive flash flood occurred due to intensive precipitation, and discharges reached high values (Pilica: $141 \mathrm{~m}^{3} \mathrm{~s}^{-1}$, Luciaza: 35.2 $\mathrm{m}^{3} \mathrm{~s}^{-1}$ ) in a short time (10 days), which destabilised the established equilibrium of the reservoir ecosystem. Water temperature varied from $21^{\circ} \mathrm{C}$ to $24^{\circ} \mathrm{C}$ from June to the end of August. The coldest month was September, when the mean temperature was $17^{\circ} \mathrm{C}$, which mostly resulted from the long period of heavy rain. Density of YOY Percids was 0.1 ind. $\mathrm{m}^{-3}$. "Edible" phytoplankton (mainly diatoms Cyclotella comensis and Cyclotella radiosa) dominated at the end of July (maximal biomass $18 \mathrm{mg} \mathrm{dm}^{-3}$ ) and between August and September (maximal biomass $13.18 \mathrm{mg} \mathrm{dm}^{-3}$ ). A high biomass of cyanobacteria appeared at the end of July (dominating species: Microcystis aeruginosa and Aphanizomenon flos-aquae reached $24.36 \mathrm{mg} \mathrm{dm}^{-3}$ ). The second peak of cyanobacteria biomass was observed at the end of August (10.18 $\mathrm{mg} \mathrm{dm}^{-3}$ ). Biomass of Daphnia sp. increased in the third week of June and then decreased during the flash flood. The maximum Daphnia biomass $\left(28 \mathrm{mg} \mathrm{dm}^{-3}\right)$ was observed in the first week of July. A midsummer decrease in the Daphnia population (to $5 \mathrm{mg} \mathrm{dm}^{-3}$ ) occurred between July and August. A maximal value of $L$. kindtii biomass $\left(25 \mathrm{mg} \mathrm{dm}^{-3}\right)$ was observed in July. High Leptodora biomass also persisted in August and September $\left(15 \mathrm{mg} \mathrm{dm}^{-3}\right)$ (Fig. 5).

Initial values of the model were: a Daphnia cucullata biomass of $1.41 \mathrm{mg} \mathrm{dm}^{-3}$, L. kindtii biomass of $3.33 \mathrm{mg}$ $\mathrm{dm}^{-3}$, and a juvenile Percid density of 0.1 ind. $\mathrm{m}^{-3}$. The model simulation showed an overall pattern of zooplankton dynamics similar to the observed one, but only under the stable hydrological conditions. A decline of Daphnia biomass between June and July, due to hydrological disturbance was not reflected by the model, as it did not include this parameter (Fig. 5).

\section{Year 2000}

The overall hydrological pattern in 2000 was characterised by stable hydrological conditions during June, July and September and a flash flood in August $\left(112 \mathrm{~m}^{3}\right.$ $\left.\mathrm{s}^{-1}\right)$. It was the warmest year, with a mean water temperature of $22-24^{\circ} \mathrm{C}$ until the end of August, and $12^{\circ} \mathrm{C}$ in the last week of September. Juvenile Percids appeared at a density of 0.2 ind. $\mathrm{m}^{-3}$. Biomass of Bosmina sp. reached a maximum during the high water inflow $\left(27 \mathrm{mg} \mathrm{dm}^{-3}\right)$. 




Fig. 5. Calibration of the model for 1999: a) water inflow; b) dynamics of Bosmina sp. biomass in the field; c) empirical data of Daphnia sp. (left axis) and L. kindtii (right axis) biomass dynamics; and d) the model simulations of Daphnia sp. (left axis) and $L$. kindtii (right axis) biomass dynamics.

"Edible" phytoplankton were observed throughout the whole season with the highest biomass of diatoms in the second part of July $\left(22 \mathrm{mg} \mathrm{dm}^{-3}\right)$. The "clear water phase" was very short and appeared between June and July. The biomass of cyanobacteria was generally low and any blooms were observed in 2000. Dynamics of Daphnia sp. biomass were characterised by maximal values in June (30 $\mathrm{mg} \mathrm{dm}^{-3}$ ) and drastic decreases (to $2 \mathrm{mg} \mathrm{dm}^{-3}$ ) during July (midsummer decline). Daphnia biomass increased in mid-August (to $15 \mathrm{mg} \mathrm{dm}^{-3}$ ) and persisted at a level of $10-13 \mathrm{mg} \mathrm{dm}^{-3}$ until September. Biomass of $L$. kindtii increased in the end of June (stimulated by still high biomass of daphnids) and achieved a maximum in July $\left(40 \mathrm{mg} \mathrm{dm}^{-3}\right)$. During August, the biomass of Leptodora decreased to $10 \mathrm{mg} \mathrm{dm}^{-3}$. In September, Leptodora varied between 1.5-6 $\mathrm{mg} \mathrm{dm}^{-3}$ (Fig. 6).

Initial values of the model were: Daphnia cucullata biomass $13.89 \mathrm{mg} \mathrm{dm}^{-3}$, L. kindtii biomass $8.23 \mathrm{mg} \mathrm{dm}^{-3}$, juvenile Percid density was 0.2 ind. $\mathrm{m}^{-3}$. Results of the DALIS simulation was similar to those observed in the field. However, the model showed a shorter peak of Leptodora in July. In consequence, the increase of Daphnia biomass appeared earlier in the model simulation. In

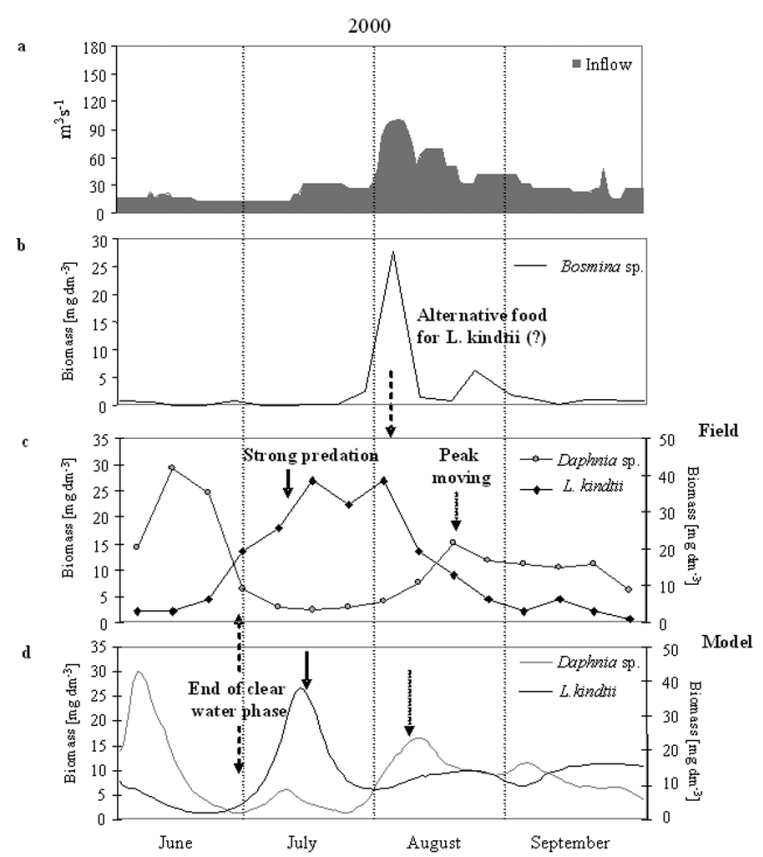

Fig. 6. Calibration of the model for 2000: a) water inflow; b) dynamics of Bosmina sp. biomass in the field; c) empirical data of Daphnia sp. (left axis) and L. kindtii (right axis) biomass dynamics; and d) the model simulations of Daphnia sp. (left axis) and L. kindtii (right axis) biomass dynamics.

September, the modelled biomass of Leptodora was higher than in the field observations (Fig. 6).

\section{Year 2001}

Hydrological conditions in 2001 were relatively unstable. A long period of high inflows $120 \mathrm{~m}^{3} \mathrm{~s}^{-1}$ ) appeared between July and August. The year was rather cold, and the mean water temperature in June amounted to $18-19^{\circ} \mathrm{C}$, from July to August $-21-23^{\circ} \mathrm{C}$ and $16^{\circ} \mathrm{C}$ during September. Juvenile Percid density was 0.5 ind. $\mathrm{m}^{-3}$. Biomass of Bosmina sp. reached a maximum value of $15 \mathrm{mg}$ $\mathrm{dm}^{-3}$. The sequence of phytoplankton succession was typical for the Sulejow Reservoir - "edible" algae dominated in June and July (but had low biomass 5-7 mg $\left.\mathrm{dm}^{-3}\right)$. The peak cyanobacteria biomass $\left(19 \mathrm{mg} \mathrm{dm}^{-3}\right)$ appeared at the beginning of the September. The "clear water phase" occurred during the first part of June. During this time, phytoplankton composition was dominated by diatoms, green algae (Chlamydomonas sp.) and cryptophytes (Cryptomonas sp.). Biomass dynamics of zooplankton were characterised by several small peaks between June and July and in August. Daphnia sp. achieved maximal biomass (12-15 $\mathrm{mg} \mathrm{dm}^{-3}$ ) during the first and last weeks of June. At the beginning of July, a 
decrease in Daphnia biomass corresponded to a high biomass of L. kindtii $\left(15 \mathrm{mg} \mathrm{dm}^{-3}\right)$ (Fig. 7).

Initial values of the model were: a Daphnia cucullata biomass of $17.40 \mathrm{mg} \mathrm{dm}^{-3}, \mathrm{a}$ L. kindtii biomass of $4.80 \mathrm{mg}$ $\mathrm{dm}^{-3}$, and a juvenile Percid density of 0.5 ind. $\mathrm{m}^{-3}$. In this year, discrepancies between the observed and simulated results were found. The model did not reveal the peak of Leptodora biomass in June. In consequence, the simulated peak of Daphnia biomass was higher and longer than that observed in the field during this month. The next peaks of Daphnia and Leptodora biomass were shifted to the middle of July in the model simulations. In the second part of July the model showed a lower biomass of both Daphnia sp. $\left(6 \mathrm{mg} \mathrm{dm}^{-3}\right)$ and Leptodora $\left(5 \mathrm{mg} \mathrm{dm}^{-3}\right)$ than those observed in the field. In September, results of field study and the DALIS simulation were similar: biomass of Cladocera was low (Fig. 7).



Fig. 7. Calibration of the model for 2001: a) water inflow; b) dynamics of Bosmina sp. biomass in field; c) empirical data of Daphnia sp. (left axis) and L. kindtii (right axis) biomass dynamics; and d) the model simulations of Daphnia sp. (left axis) and L. kindtii (right axis) biomass dynamics.

\section{Scenarios test}

Two scenarios, with initial Daphnia biomass of 19.22 $\mathrm{mg} \mathrm{dm}{ }^{-3}$, were tested under two different conditions (A, B) of predator pressure.

Scenario I: Dynamics of a Daphnia sp. population during good food conditions; from the beginning of June to the end of August, mean biomass of "edible" phytoplankton amounted to $20 \mathrm{mg} \mathrm{dm}^{-3}$ with a short (7 days) "clear water phase" at the end of June. Cyanobacteria achieved low biomass (below $3 \mathrm{mg} \mathrm{dm}^{-3}$ ) and blooms did not appear.

Condition A: of YOY fish, with an initial biomass of Leptodora of $4.38 \mathrm{mg} \mathrm{dm}^{-3}$. The model showed (Fig. 8a) high Daphnia biomass in June (good food condition), which decreased during the "clear water phase". Simultaneously, an increasing L. kindtii biomass was observed. During July the maximal peak of Leptodora corresponded to a decline of Daphnia biomass (midsummer decline). At the beginning of August, Daphnia biomass increased, but maintained the level of $5-8 \mathrm{mg} \mathrm{dm}^{-3}$, despite a good food base. During this time biomass of $L$. kindtii was high (7-13.5 $\left.\mathrm{mg} \mathrm{dm}^{-3}\right)$.

Condition B: Lack of Leptodora, with an initial density of YOY fish of $1.88 \mathrm{ind} \mathrm{m}^{-3}$ (high density observed in the reservoir pelagial; Fig. 8b). In June, the pattern of Daphnia dynamic was similar to that in condition A. From July to the end of August, biomass of Daphnia was high and oscillated between 10 and $29 \mathrm{mg} \mathrm{dm}^{-3}$.

Scenario II: Dynamics of a Daphnia sp. population under poor food conditions characteristic of low and stabilised hydrological inflow: "edible" phytoplankton appeared to be the highest biomass $\left(12 \mathrm{mg} \mathrm{dm}^{-3}\right)$ only at the beginning of June, then the biomass decreased below $1 \mathrm{mg} \mathrm{dm}^{-3}$. From the end of July on, biomass of cyanobacteria increased and blooms $\left(80 \mathrm{mg} \mathrm{dm}^{-3}\right)$ were observed.

Condition A: Lack of YOY fish, with an initial Leptodora biomass of $4.38 \mathrm{mg} \mathrm{dm}^{-3}$ (Fig. 9a). In June, the early summer peak of Daphnia decreased during "clear water phase". In July, the small peak of Daphnia biomass $\left(6.5 \mathrm{mg} \mathrm{dm}^{-3}\right)$ appeared. Generally, the decline of Daphnia biomass was observed during the maximal peak of Leptodora (Daphnia midsummer decline). In August, which was the cyanobacteria blooming period, the Daphnia biomass (and consequently L. kindtii one) decreased almost to zero.

Condition B: Lack of Leptodora with an initial density of YOY fish of $1.88 \mathrm{ind} \mathrm{m}^{-3}$ (Fig. 9b). In June, oscillations of Daphnia biomass were similar to that in versionA. The maximal peak was observed in July. Biomass of Daphnia 
decreased at the turn of July and August when food conditions were worsening (cyanobacteria blooms).

\section{Discussion}

Many predators can substantially influence the population dynamics of their prey. In freshwater ecosystems, the presence or absence of vertebrate predators significantly contributes to shifts in the size-frequency distributions of the zooplankton community (Hrbacek et al. 1961). The role of invertebrate predators in the major reduction of zooplankton biomass is also very important (Herzig \& Auer 1990, Lunte \& Luecke 1990, Branstrator 1998, Wojtal et al. 1999). The prey respond to these selective pressures with changes in their spatial and temporal overlap with predators (density risk responses), or with changes in their vulnerability to the predator (prey vulnerability response) (Williamson et al. 1989). However, as a defence against predation may have an associated cost, it causes different restrictions (according to Williamson et al. 1989), e.g. density risk responses may be restricted to habitats where food, temperature, oxygen concentrations or other environmental factors are suboptimal for survival, growth or reproduction (Werner et al. 1983, Rose et al. 2000). In addition, vulnerability response may be limited by body shapes, sizes, or swimming modes that are suboptimal for basic physiological processes (Dodson 1984, Chang \& Hanazato 2003). This is why the influence of predation and other biotic and abiotic factors on zooplankton dynamics should not be analysed separately. The model presented pointed to the significant role of the invertebrate predator, $L$. kindtii in the reduction of Daphnia biomass during stable hydrological conditions in the summer, but, on the other hand, indicated close dependence of Daphnia population on the food base (Fig. 8,9). Although these results may seem obvious, the model simulations allow us to predict the extent to which predation disturbs the dynamics of Daphnia (and, for example, the extent to which this can contribute to midsummer decline) under different food conditions. Regardless of the intensity of predator pressure, a decrease of Daphnia biomass was observed in two cases: At the end of the "clear water phase" (Fig. 6; also confirmed by DALIS scenarios, Fig. 8, 9) and during cyanobacteria blooms (Fig. 7). However, in summer-months (mainly in July) predation could more significantly decrease Daphnia biomass (Fig. 5, 6). This pattern was especially clear in 2000 when the Daphnia midsummer decline lasted through July despite the availability of "edible" phytoplankton (Fig. 4 and 6). However, the modelled results (Fig. 8) indicated that in very good food conditions, biomass of Daphnia does not
A

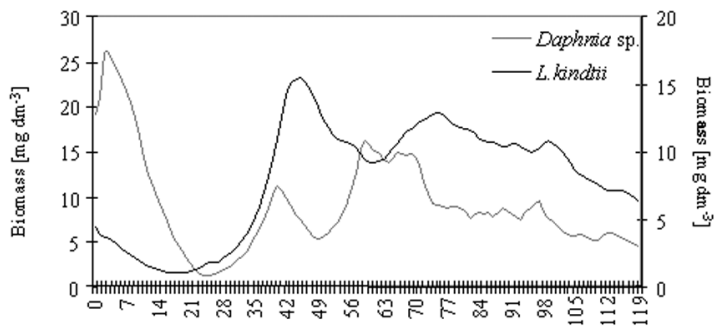

B

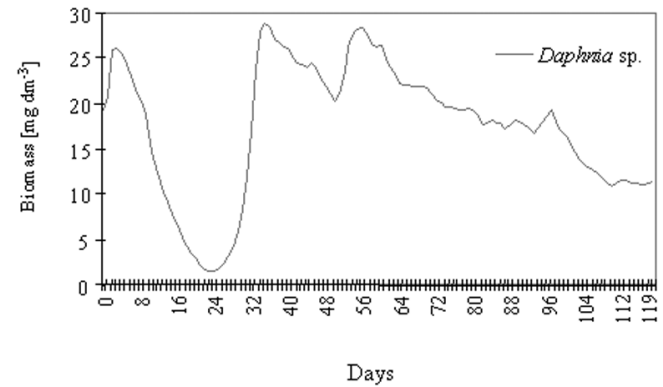

Fig. 8. The first scenario of the model simulations under good food conditions: Condition A with a high pressure of L.kindtii and a lack of YOY fish, and Condition B with YOY fish pressure and a lack of L. kindtii.

A

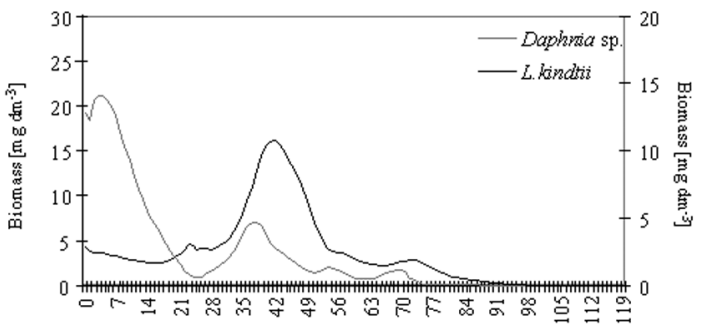

B

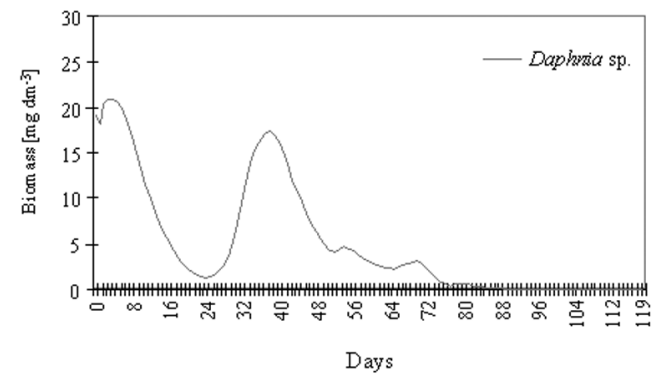

Fig. 9. The second scenario of the model simulations in poor food conditions: Condition A with a high pressure of L. kindtii and a lack of YOY fish, and Condition B with YOY fish pressure and a lack of L. kindtii. 
decrease below $5 \mathrm{mg} \mathrm{dm}^{-3}$, despite the high pressure of $L$. kindtii.Accordingly, the midsummer decline of Daphnia population was not observed, and only the short-lived decrease of its biomass was observed during high density of Leptodora (Fig. 8). It seems probable that the midsummer decline of Daphnia biomass under poor food conditions resulted from summarising the effect of predation and lack of "edible" phytoplankton (Fig. 9). It is worth pointing out that the results of model simulations demonstrate that in some periods Leptodora may play a more significant role in the reduction of Daphnia biomass than YOY fish. According to literature, Leptodora can alter the age structure of their prey population by removing juvenile individuals and thus increasing the proportion of adults (Vijverberg et al. 2005). In consequence, Leptodora may contribute to the enhancement of the per capita birth rate of large-bodied cladocerans, in this way modulating the downward oscillation of the prey population and dampening the amplitude of the predator cycle (Polishchuk 1995). However, as Leptodora usually achieved very high densities in the Sulejow Reservoir (Wojtal et al. 1999, 2004), such a mechanism might be not observed. This fact is unfavourable to our biomanipulation activities.

YOY pikepearch was the main zooplanktivorous fish in the pelagic zone of the Sulejow Reservoir during early summer (Frankiewicz et al. 1996). The simulated scenarious confirmed our earlier empirical results (Wojtal et al. 2004) that the influence of potentially planktivorous fish on zooplankton dynamics in the pelagic zone of the reservoir is insignificant. This is a consequence of the low density of juvenile Percids in the Reservoir pelagial. Our earlier study also indicates that most of the adult Cyprinids, especially roach and silver bream, preferred Dreissena polymorpha (Pallas) as a food, and preyed significantly upon daphnids only in June when the large-bodied filtrators achieved their highest densities (e.g. up to $20 \mathrm{~g} \mathrm{~m}^{-3}$ in 1996 and 1998) and a high rate of reproduction(Frankiewiczetal.2002). At that time, even intensive filtration by fish could not overtake the actual rate of zooplankton reproduction (Wojtal 2000). When zooplankton density started to decline, Cyprinids immediately switched to an alternative food (Frankiewiczet al. 2002).

Biotic interactions determining the dynamics of zooplankton in lowland reservoirs have been investigated, and are relatively well recognised by several authors. These interactions are summarised in the middle part of the Fig. 10. These interactions may be altered, however by hydrological characteristics of the ecosystem. Relatively invariable water inflow to the reservoir with small amplitudes, supports a balanced pattern of biotic interactions
(Fig. 5, 6), as described by classical ecological theories concerning prey-predator interactions and food resource competition. Also, the simulations of the DALIS (1.0) model, gave good descriptions of the ecosystem behaviour under stable abiotic conditions. According to one of the principles of Ecohydrology (Zalewski et al. 1997), biotic interactions are most evident under stable and optimal abiotic conditions. Hydrological disturbances (e.g. flash floods, long and deep droughts) destabilise biotic interactions and may change or reverse a succession pattern and the structure of an ecosystem (Zalewski \& Naiman 1985, Zalewski et al. 2000). In the present study, there were discrepancies between the observed and simulated results during or after periods of floods, as the current model did not include hydrological parameters. However, the model yielded interesting results: unstable hydrological conditions seriously disturb biotic interactions; and floods may have a double effect on the dynamics of zooplankton (Fig. 5, 7). The first, resulting from hydrological disturbances, is the reduction or shifting in time of the appearance of zooplankton biomass peak (Fig. 6). The other results from the supply of the reservoir with a considerable amount of organic suspended matter, which supplies the food base for small filtrators, like Bosmina sp. or Chydorus sp. As the small-bodied cladoceran seemingly utilise the smallest fraction of the summer food resource and feed on bacteria (Gliwicz \& Siedlar 1980), they often appear in high densities after high flow. It is probably during this time that Bosmina may become an alternative food for Leptodora, which is large and less susceptible than Daphnia to being washed away. Such a scenario was observed in August of 2000 (Fig. 6) and in June of 2001 (Fig. 7). Generally unstable hydrological conditions, as observed in 2001, prevent strong interactions between Daphnia and Leptodora from being manifested (Fig. 7). The analogous influence of floods on the species composition of zooplankton was observed on another Polish Dobczyce Reservoir (Godlewska et al. 2003). The presented results suggest that hydrological parameters should also be considered and added in the further development of the model.

In conclusion, intensive algal blooms, as one of the consequences of eutrophication, pose significant problems for use of the Sulejow Reservoir. It has been suggested that the restoration project (Zalewski et al. 1990) should consist of a series of activities, both planned and already implemented, which utilise the biological properties of the ecosystems in such a way as to improve water quality in the reservoir. In connection with fact that maintenance of high Daphnia densities is regarded as a key factor in top-down efforts, the DALIS 1.0 model can be applied in the future to predict zooplankton biomass 




Fig. 10. A schema summarizing the most important factors influencing Daphnia dynamics (according to Wojtal 2004; modified). Effects of hydrology signify: the zooplankton washing away effect; zooplankton peaks shifting and inflow influences on increasing alternative foods (animal flagellates for Daphnia sp. or small Cladocera, like Bosmina sp. for L. kindtii).

dynamic and the appearance of the midsummer decline of the Daphnia population. The DALIS algorithm may also be useful for predicting trophic interactions in other lowland reservoirs of similar biotic and abiotic characteristics.

\section{Acknowledgements}

The authors are grateful to Professor Sven Jorgensen and Dr. Jingjie Zhang for their helpful comments on the presented model. This research was supported under Grant No. 3 PO4 G 05023 of the Polish National Research Committee.

\section{References}

Benndorf J., Wissel B., Sell A. F., Hornig U., Ritter P. \& Boing W. 2000. - Food web manipulation by extreme enhancement of piscivory: an invertebrate predator compensates for the effects of planktivorous fish on a plankton community. Limnologica, 30, 235-245.

Benndorf J., Kranich J., Mehner T. \& Wagner A. 2001. Temperature impact on the midsummer decline of Daphnia galeata: an analysis of long-term data from biomanipulated Bautzen Reservoir (Germany). Freshwat. Biol., 46 (2), 199-211.

Boersma M., van Tongeren O.F.R. \& Mooij W.M. 1996. - Seasonal patterns in the mortality of Daphnia species in a shallow lake. Can. J. Fish. Aquat. Sci., 53, 18-28.

Bottrell H.H., Duncan A., Gliwicz Z.M., Grygierek E., Herzig A., Hilbricht-Ilkowska A., Krasawa H., Larsson P. \& Weglenska T. 1976. - A review of some problems in zooplankton production studies. Norw. J. Zool., 24, 419-456.

Branstrator D.K. 1998. - Predicting diet composition from body length in the zooplankton predator Leptodora kindtii. Limnol. Oceanogr., 43 (3), 530-535.

Branstrator D.K. \& Lehman J. T. 1991. - Invertebrate predation in Lake Michigan: regulation of Bosmina longirostris by Leptodora kindtii. Limnol. Oceanogr., 36, 483-495. 
Carmichael W.W. 1992. - Cyanobacteria secondary metabolites the cyanotoxins. J. Appl. Bacteriol., 72, 445-459.

Carney J.J. \& Elser J.J. 1990. - The strength of zooplankton-phytoplankton coupling in relation to trophic state. Pages 616-631 in Ecology of large lakes. Tilzer M.M. (ed.). Springer-Verlag, New York.

Chang K.H. \& Hanazato T. 2003. - Seasonal and reciprocal succession and cyclomorphosis of two Bosmina species (Cladocera, Crustacea) co-existing in a lake: their relationship with invertebrate predators. J. Plankton Res., 25 (2), 141-150.

Cryer M., Peirson G. \& Townsend C.R. 1986. - Reciprocal interactions between roach, Rutilus rutilus, and zooplankton in a small lake: Prey dynamics and fish growth and recruitment. Limnol. Oceanogr., 31, 1022-1038.

De Mott W.R. 1989. - The role of competition in zooplankton succesion. Pages 195-252 in Plankton Ecology. Sommer U. (ed.). Springer-Verlag, Berlin.

De Stasio B.T. Jr, Rudstam L.G., Haning A., Soranno P. \& Allen Y.C. 1995. - An in situ test of the effect of food quality on Daphnia population growth. Hydrobiologia, 307, 221-230.

Dodson S.C. 1984. - Predation of Heterocope septentrionalis on two species of Daphnia: Morphological defences and their cost. Ecology, 65, 1249-1257.

Elliot J.M. \& Persson L. 1978. - The estimation of daily rates of food consumption for fish. J. Anim. Ecol., 47, 977-991.

Falconer I.R. 1994. - Health Problems for Exposure to Cyanobacteria and Proposed Safety Guidelines for Drinking and Recreational Water. Pages 3-10 in Detection Methods for Cyanobacterial Toxins. Codd G.A., Jefferies T.M., Keevil C.W. \& Potter E. (eds). The Royal Society of Chemistry, Cambridge, UK.

Frankiewicz P., Dabrowski K. \& Zalewski M. 1996. - Mechanism of establishing bimodality in a size distribution of age-0 pikeperch, Stizostedion lucioperca (L.) in the Sulejow Reservoir, Central Poland. Ann. Zool. Fennici, 33, 321-327.

Frankiewicz P., Dabrowski K., Martyniak A. \& Zalewski M. 1999. Cannibalism as a regulatory force of pikeperch, Stizostedion lucioperca (L.), population dynamics in the lowland Sulejow Reservoir (Central Poland). Hydrobiologia, 408/409, 47-55.

Frankiewicz P., Wojtal A. \& Zalewski M. 2002. - Temporal and spatial pattern of zooplanktivory by $0+$ fish and older cyprinids in the zebra mussel dominated lowland reservoir. Pages 93-95 in extended abstracts $4^{\text {th }}$ International Conference: "Reservoir Limnology and Water Quality". Ceske Budejovice, Czech Republik.

Garton D.W., Berg D.J. \& Fletcher R.J. 1990. - Thermal tolerances of the predatory Cladocerans Bythotrephes cederstroemi and Leptodora kindtii: relationship to abundance in western Lake Erie. Can. J. Fish. Aquat. Sci., 47, 731-738.

Gliwicz Z.M. 1977. - Food size selection and seasonal succession of filter feeding zooplankton in an eutrophic lake. Ekol. Pol., 25, 179-225.

Gliwicz Z.M. \& Prejs A. 1977. - Can planktivorous fish keep in check planktonic crustacean populations? A test of the size-efficiency hypothesis in typical polish lakes. Ekol. Pol., 25, 567-591.

Gliwicz Z.M. \& Siedlar E. 1980. - Food size limitation and algae interfering with food collection in Daphnia. Arch. Hydrobiol., 88, 155-177.

Gliwicz Z.M. \& Pijanowska J. 1989. - The role of predation in zooplankton succession. Pages 253-295 in Plankton Ecology: Succession in Plankton Communities. Sommer U. (ed.). Springer, Berlin, Heidelberg, New York.
Godlewska M., Mazurkiewicz-Boro G., Pociecha A., Wilk-Woniak E. \& Jelonek M. 2003. - Effects of flood on the functioning of the Dobczyce reservoir ecosystem. Hydrobiologia, 504, 305-313.

Hambright K.D. 1994. - Morphological constraints in the piscivore-planktivore interactions: Implications for the trophic cascade hypothesis. Limnol. Oceanogr., 39, 897-912.

Hannon B. \& Ruth M. 2001. - Modelling Dynamic Biological Systems. Springer, New York, 398 p.

Harper D. 1992. - Eutrophication of Freshwaters. Principles, problems and restoration. Chapman \& Hall, London, New York, Tokyo, Melbourne, Madras, 327 p.

Herzig A. 1994. - Predator-prey relationship within the pelagic community of Neusiedler See. Hydrobiologia, 275/276, 81-96.

Herzig A. 1995. - Leptodora kindti: efficient predator and preferred prey item in Neusiedler See. Hydrobiologia, 307, 273-282.

Herzig A. \& Auer B. 1990. - The feeding behaviour of Leptodora kindti and its impact on the zooplankton community of Neusiedler See (Austria). Hydrobiologia, 198, 107-117.

Horn W. 1991. - The influence of biomass and structure of the crustacean plankton on the water transparency in the Saidenbach storage reservoir. Hydrobiologia, 225, 115-120.

Hrbacek J., Dvorakova M., Korinek V. \& Prochazkova L. 1961. Demonstration of the effect of the fish stock on the species composition of zooplankton and the intensity of metabolism of the whole plankton association. Verh. Int. Ver. Limnol., 14 192-195.

Hillbricht-Ilkowska A. \& Karabin A. 1970. - An attempt to estimate consumption, respiration and production of Leptodora kindtii (Focke) in field and laboratory experiments. Pol. Arch Hydrobiol., 17 (30), 81-86.

Hulsmann S. \& Mehner T. 1997. - Predation by underyearling perch (Perca fluviatilis) on a Daphnia galeata population in a short-term enclosure experiment. Freshwat. Biol., 38, 209-219.

Ivanova M.B. 1985. - Produktsiya planktonnyh rakoobraznyh $v$ presnyh vodah. [Production of planktonic crustaceans in fresh water]. Leningrad, 222 p. (in Russian).

Jeppesen E. 1998. - The ecology of shallow lakes. Trophic interactions in the pelagial (DSc). NERI Technical Report, 247, $358 \mathrm{p}$.

Jeppesen E., Jensen J.P., Jensen C., Faafeng B., Hessen D.O., Sondergaard M., Lauridsen T., Brettum P. \& Christoffersen K. 2003. - The impact of nutrient state and lake depth on top-down control in the pelagic zone of lakes: a study of 466 lakes from the temperate zone to the arctic. Ecosystems, 6, 313-325.

Jorgensen S.E. \& De Bernardi R. 1998. - The use of structural dynamic models to explain successes and failures of biomanipulation. Hydrobiologia, 379,147-158.

Jorgensen S.E., Jorgensen L.A., Kamp-Nielsen L. \& Mejer H.F. 1981. - Parameter estimation in eutrophication modelling. Ecol. Model., 13, 111-125.

Jurczak T., Tarczynska M., Karlsson K. \& Meriluoto J. 2004. Characterization and diversity of cyanobacterial hepatotoxins (Microcystins) in blooms from polish freshwaters identified by liquid chromatography-electrospray ionization mass spectrometry. Chromatographia, 59, 571-578.

Karabin A. 1974. - Studies on the predatory role of the Cladoceran, Leptodora kindtii (Focke), in secondary production of two lakes with different trophy. Ekol. Pol., 22, 295-310.

Kmet T. \& Straskraba M. 2004. - Feeding adaptation of filter feeders: Daphnia. Ecol. Model., 178, 313-327.

Krebs J.R. \& Stephans D.W. 1986. - Foraging Theory. Princeton University Press, Princeton, NJ. 
Lunte, C.C. and Luecke, C. (1990) Trophic interactions of Leptodora in Lake Mendota. Limnol. Oceanogr., 35 (5), 1091-1100.

Matveev V. 1995. - The dynamics and relative strength of bottom-up vs top-down impacts in a community of subtropical lake plankton. Oikos, 73, 104-108.

Mehner T., Schultz H., Bauer D., Herbst R., Voigt H. \& Benndorf J. 1996. - Intraguild predation and canibalism in age-0 perch (Perca fluviatilis) and age-0 zander (Stizostedion lucioperca): interactions with zooplankton succession, prey availability and temperature. Ann. Zool. Fennici, 33, 353-361.

Mehner T., Hulsmann S., Worischka S., Plewa M., \& Benndorf J. 1998. - Is the midsummer decline of Daphnia really induced by age-0 fish predation? Comparison of fish consumption and Daphnia mortality and life history parameters in a biomanipulated reservoir. J. Plankton Res., 20 (9), 1797-1811.

Mills T.E., Forney J.L., \& Wagner K.J. 1987. - Fish predation and its cascading effect on the Oneida Lake food chain. Pages 118-131 in Predation. Direct and indirect impacts on aquatic communities. Kerfood W.C. \& Sih A. (eds.). University Press of New England, Hanover and London.

Moore M.V., Folt C.L. \& Stemberger R.S. 1996. - Consequences of elevated temperatures for zooplankton assemblages in temperate lakes. Arch. Hydrobiol., 135, 289-319.

Nebaeus M. 1984. - Algal water-blooms under ice-cover. Verh. Int. Ver. Limnol., 22, 719-724.

Polishchuk L.V. 1995. - Direct positive effect of invertebrate predators on birth rate in Daphnia studied with a new method of birth rate analysis. Limnol. Oceanogr., 40, 483-489.

Prus T. 1970. - Calorific value of animals as an element of bioenergetical investigations. Pol. Arch. Hydrobiol., 17 (30), 183-199.

Reynolds C.S. 1984. - The Ecology of Freshwater Phytoplankton. Freshwater Biological Association, University Press, Cambridge, $384 \mathrm{p}$.

Rinke K. \& Vijverberg J. 2005. - A model approach to evaluate the effect of temperature and food concentration to individual life-history and population dynamics of Daphnia. Ecol. Model., 186, 326-344.

Rose R.M., Warne M. St. J. \& Lim R.P. 2000. - Life history responses of the cladoceran Ceriodaphnia cf. dubia to variation in food concentration. Hydrobiologia, 427, 59-64.

Shapiro J. 1980. - The importance of trophic level interactions to the abundance and species composition in lakes. Dev. Hydrobiol., 2, 105-116.

Sommer U., Gliwicz Z. M., Lampert W. \& Dunkan A. 1986. - The PEG-model of seasonal succession of planktonic events in fresh waters. Arch. Hydrobiol., 106, 433-471.

Sorokin Y.I. 1999. - Aquatic Microbial Ecology. A textbook for students in environmental sciences. Backhuys Publishers, Leiden, $247 \mathrm{p}$.

Straskraba M. \& Tundisi J.G. 1999. - Reservoir ecosystem functioning: theory and application. Pages 565-597 in Theoretical Reservoir Ecology and its Applications. M. Staskraba \& J.G. Tundisi (eds). Backhuys Publishers, The Netherlands.

Sterner R.W. 1989. - The role of grazers in phytoplankton succession. Pages 107-170 in Plankton Ecology: Succession in Plankton Communities. Sommer U. (ed.). Springer, Berlin, Heidelberg, New York.

Sushchenya L.M. 1972. - Intensivnost dyhaniya rakoobraznykh. [Respiration intensity of crustaceans]. Kiev, 195 p. (in Russian).

Tarczynska M., Romanowska-Duda Z., Jurczak T. and Zalewski M. 2001. - Toxic cyanobacterial blooms in drinking water reservoir - causes, consequences and management strategy. Wat. Sci. Technol.: Water Supply, 1 (2), 237-246.

Werner E.E., Gilliam J.F., Hall D.J. \& Mittelbach G.G. 1983. - En experimental test of the effects of predation risk on habitat use in fish. Ecology, 64, 1540-1548.

Williamson C.E., Stoeckel M.E. and Schoeneck L.J. 1989. Predation risk and the structure of freshwater zooplankton communities. Oecologia, 79, 76-82.

Winberg G.G. 1968. - Metody opredelenija produktsii vodnyh zhivotnyh. [Methods of estimating the production of aquatic animals]. Leningrad, 245 p. (in Russian).

Wootton R.J. 1990. - Ecology of Teleost Fishes. Chapman and Hall, London, New York, 404 p.

Wojtal A. 2000. - Analysis of the trophic interactions connected with cascading effect in littoral and pelagic zone of Sulejow Reservoir. PhD-Thesis, University of Lodz, Poland, 149 p. (in Polish).

Wojtal A. 2004. - Surveys: How to assess and quantify specific issues in watersheds? Lakes and Reservoirs: Zooplankton. Pages 116-120 in Integrated Management of the Watershed Phytotechnology and Ecohydrology - Manual. Zalewski M. \& Wagner-Lotkowska I. (eds.). IHP/UNDP/UNESCO, 38.

Wojtal A., Frankiewicz P. \& Zalewski M. 1999. - The role of the invertebrate predator Leptodora kindti in the trophic cascade of a lowland reservoir. Hydrobiologia, 416, 215-223.

Wojtal A., Frankiewicz P., Wagner-Lotkowska I. \& Zalewski M. 2004. - The evaluation of the role of pelagic invertebrate versus vertebrate predators on the seasonal dynamics of filtering Cladocera. Hydrobiologia, 515, 123-135.

Wu L. \& Cluver D.A. 1992. - Ontogenetic diet shift in Lake Erie age-0 yellow perch (Perca flavescens): a size-related response to zooplankton density. Can. J. Fish. Aquat. Sci., 49, 1932-1937.

Vander Zanden M. J. \& Vadebonceur Y. 2002. - Fish as integrators of benthic and pelagic food webs in lakes. Ecology, 83, 2152-2161.

Vijverberg J., Koelewijn H.P. \& van Densen W.L.T. 2005. - Effects of predation and food on the population dynamics of the raptorial cladoceran Leptodora kindtii. Limnol. Oceanogr., 50 (2), 455-464.

Zalewski M. 1999. - Minimising the risk and amplifying the opportunities for restoration of shallow reservoirs. Hydrobiologia, 395/396, 107-114.

Zalewski M. \& Naiman R. J. 1985. - The regulation of riverine fish communities by continuum of abiotic-biotic factors. Pages 3-9 in Habitat Modification and Freshwater Fisheries. Alabaster J. S. (ed.). FAO/UN/Butterworths Scientific Ltd, London.

Zalewski M., Brewinska-Zara B., Frankiewicz P. \& Kalinowski S. 1990. - The potential for biomanipulation usig fry communities in a lowland reservoir: concordance between water quality and optimal recruitment. Hydrobiologia, 200/201, 549-556.

Zalewski M., Janauer G.A., \& Jolankaj G. 1997. - Ecohydrology: A New Paradigm for the Sustainable Use of Aquatic Resources. Conceptual Background, Working Hypothesis. Rationale and Scientific Guidelines for the Implementation of the IHP-V Projects 2.3/2.4 UNESCO, Paris, 58 p.

Zalewski M., Wagner-Lotkowska I. \& Tarczynska M. 2000. Ecohydrological approaches to the elimination of toxic algal blooms in lowland reservoir. Verh. Int. Ver. Limnol., 27, 3176-3183. 
